\title{
HEGESZTÉS SORÁN KELETKEZŐ FUTTATÁSI SZÍNEK FIZIKAI SZIMULÁCIÓJA
}

\author{
Rozsnyai László \\ hallgató, Miskolci Egyetem, Anyagszerkezettani és Anyagtechnológiai Intézet \\ 3515 Miskolc, Miskolc-Egyetemváros, e-mail: tqit.laci@gmail.com \\ Kuzsella László \\ egyetemi docens, Miskolci Egyetem, Anyagszerkezettani és Anyagtechnológiai Intézet \\ 3515 Miskolc, Miskolc-Egyetemváros, e-mail: kuzsella@uni-miskolc.hu

\section{Bassel Alsalamah} \\ Ph.D hallgató, Miskolci Egyetem, Anyagszerkezettani és Anyagtechnológiai Intézet \\ 3515 Miskolc, Miskolc-Egyetemváros, e-mail: bassel.alsalamah@gmail.com
}

\begin{abstract}
Absztrakt
A hegesztés a fémek esetén az egyik leggyakrabban alkalmazott kötéstechnológia. Alkalmazása széles körben elterjedt mind hobbi, kis-, közép-és nagyvállalat esetén egyaránt. Ennek köszönhetöen sokféle hegesztő eljárás jött létre, és a mai napig bövül a számuk úgynevezett „,modern eljárásváltozatok” néven, illetve egyre nagyobb teret hódit az automatizált robothegesztés.

Ívhegesztés esetén a hegesztés környezetében a höhatás övezetben a maximális hömérsékletnek megfelelöen az acél felületének szine széles szinskálán változik. Vagyis, az acél felületének szine alapján meg lehet állapitani az anyag, hegesztés közben, adott helyen elért maximális hömérsékletét.

A cikkben egy olyan vizsgálatsorozatot mutatunk be, melynek során a GLEBBLE 3500 termomechanikus fizikai szimulátor segitségével adott hömérsékletre melegitve az S355J2N acélminöségü próbatestet, a felületen keletkezett oxidréteg szinét vizsgáltuk. Ezáltal később lehetöség nyilhat hegesztett kötés esetén megállapitani, milyen maximális hömérsékletre melegedtek fel a höhatásövezet egyes részei azonos anyagminöség esetén, aminek segitségével meg lehet becsülni az adott helyen kialakult szövetszerkezetet és a várható mechanikai tulajdonságokat is.
\end{abstract}

Kulcsszavak: futtatási szín, fizikai szimuláció, hegesztett kötés

\begin{abstract}
Welding is one of the most commonly used joining technologies in metalworking. Its use is widespread in every field of the industry, ranging from small, local businesses to huge industrial companies. Thanks to this, numerous welding techniques were invented, and the number of so-called ,modern welding processes" keeps growing by the day, in addition to the new advanced, but steadily improving automated welding robots.

During the process of arc welding, the surface of the steel changes its colour according to the maximum temperature of the heated area. Consequently, the maximum temperature of a given area during the welding process can be determined with the help of the colour of the steel surface.

In the article, we present a series of tests, in which we examine the colour of the generated oxid layer on the surface of the S355J2N steel test specimen, by heating the object to the required temperature with the help of the GLEBBLE 3500 termomechanical physical simulator. Thus in the future we might
\end{abstract}


have the opportunity to determine the maximum temperature of parts of the heated area, in case of same materials grade. As a result, the expected mechanical properties, and the developed microtexture of the particular areas might be estimated.

Keywords: oxidation colour, physical simulation, weld, heat affected zone

\section{Bevezetés}

Ívhegesztéskor a hegesztés környezetében a höhatás övezetben a maximális hőmérsékletnek megfelelően az acél felületének színe széles színskálán változik. Vagyis, az acél felületének színe alapján meg lehet állapítani az anyag, hegesztés közben, adott helyen elért maximális hömérsékletét [1].

A cikkben egy olyan vizsgálatsorozatot mutatunk be, melynek során a GLEBBLE 3500 termomechanikus fizikai szimulátor segítségével adott hőmérsékletre melegítve az S355J2N acélminőségü próbatestet, a felületén keletkezett oxidréteg színét vizsgáltuk. Ezáltal később lehetőség nyílhat hegesztett kötés esetén megállapítani, milyen maximális hőmérsékletre melegedtek fel a hőhatásövezet egyes részei azonos anyagminőség esetén, ennek segítségével meg lehet becsülni az adott helyen kialakult szövetszerkezetet és a várható mechanikai tulajdonságokat is.

\section{Vizsgálatok}

\subsection{Vizsgálatra választott alapanyag (S355J2N)}

A bemutatott vizsgálatsorozat során alkalmazott S355J2 jelölésü acélminőség az általános rendeltetésü ötvözetlen szerkezeti acélok népes csoportjába tartozik, kis széntartalom és általában 500 és $600 \mathrm{MPa}$ közötti szakítószilárdság jellemzi [2]. Hidegen történő alakításra, mint kovácsolás, hajlítás korlátozottan alkalmas, de szokás alkalmazni. Hegesztésre az anyagminőség mindegyik kivitele, azaz a JR, J0, J2 is kiválón alkalmas. Korábbi, leginkább elterjedt jelölése az St 52-3, gyártási szabványa jelenleg az EN 10025-5:2005 [2]. Az anyagminőség kémiai összetételét tömegszázalékban az 1. táblázat, a jellemző mechanikai tulajdonságait a 2. táblázat tartalmazza.

1. táblázat. A vizsgált acélminöség kémiai összetétele [2]

\begin{tabular}{|c|c|c|c|c|c|}
\hline $\mathrm{C}$ wt $\%$ & Si wt\% & Mn wt\% & P wt\% & S wt\% & Cu wt\% \\
\hline$\leq 0,2$ & $\leq 0,55$ & $\leq 1,6$ & 0,025 & 0,035 & $\leq 0,55$ \\
\hline
\end{tabular}

2. táblázat. A vizsgált acélminőség jellemzö mechanikai tulajdonságai [2]

\begin{tabular}{|l|c|c|c|}
\hline & $\begin{array}{c}\text { Folyáshatár, } \\
\mathrm{R}_{\mathrm{p} 0,2}(\mathrm{MPa})\end{array}$ & $\begin{array}{c}\text { Szakítószilárdság } \\
\mathrm{R}_{\mathrm{m}}(\mathrm{MPa})\end{array}$ & $\begin{array}{c}\text { Nyúlás } \\
\mathrm{A}(\%)\end{array}$ \\
\hline Minimum & 275 & 450 & 17 \\
\hline Maximum & 355 & 630 & 20 \\
\hline
\end{tabular}

\subsection{Fizikai szimuláció, GLEEBLE 3500 termomechanikus rendszer}

Az anyagfeldolgozó eljárások fizikai szimulációja olyan laboratóriumi körülmények között végzett modellezést jelent, amely során pontosan reprodukáljuk azokat a termikus és mechanikus folyamato- 
kat, amelyek a tényleges feldolgozás során érik az adott anyagot [3]. A végső felhasználás körülményeit létrehozva az anyag vagy szerkezet müködés közbeni viselkedését is vizsgálhatjuk, a hatásokat elemezhetjük [4].

Jelen esetben a vizsgálatsorozat szempontjából kifejezve „A fizikai szimuláció nem más, mint a tényleges és a lehetséges ipari - esetünkben anyagtechnológiai - folyamatok megvalósítása, a valósággal egyező időléptékben és a valóságot relevánsan megközelítő geometriai (térfogati) léptékben [5]."

A Miskolci Egyetem Gépészmérnöki és Informatikai Karának Anyagszerkezettani és Anyagtechnológiai Intézetében rendelkezésre áll egy GLEEBLE 3500-as teljes körúen integrált, digitálisan zártkörüen vezérelt termo-mechanikai vizsgáló rendszer, Windows alapú szoftveres számítógép támogatással, amely lehetővé teszi a széleskörü termo-mechanikai vizsgálatok és szimulációk elvégzését [3].

A berendezés három fő egységre osztható, a termikus, a mechanikai egység és a digitális vezérlö rendszer. Jelen esetben csak a termikus részét használtuk a berendezésnek. A vizsgálati hőmérsékletet minden esetben nagy pontossággal, $\pm 2{ }^{\circ} \mathrm{C}$ intervallumban tudta biztosítani $[6,7]$.

A vizsgálatokat megelőzően a választott anyagminőségből próbatesteket munkáltunk ki. A vizsgálatsorozat elején a próbatestek geometriájának meghatározása során, elsődleges szempont az volt, hogy minél könnyebben lehessen a fizikai szimulátorba szerelni a vizsgálathoz. A GLEEBLE esetén az egyik leggyakrabban alkalmazott próbatest geometria a $\varnothing 10 \mathrm{~mm}$ és $110 \mathrm{~mm}$ hosszúságú henger, ezért a vizsgálatok ilyen geometriájú próbatesten kezdődtek. Ezen geometria esetén rendelkezésre álltak a megfogatást ill. az ettől is fontosabb, elektromos hozzávezetést biztosító elektródok.

A termoelem(ek) felhegesztése és a próbatest befogása után a színek rögzítésére használt, állványon rögzített Canon EOS 1100D típusú fényképezőgép 1. ábra szerinti pozícionálása következett. A cél, a különböző hőmérsékleteken keletkező különböző színủ oxid-rétegek előállítása és vizsgálata.

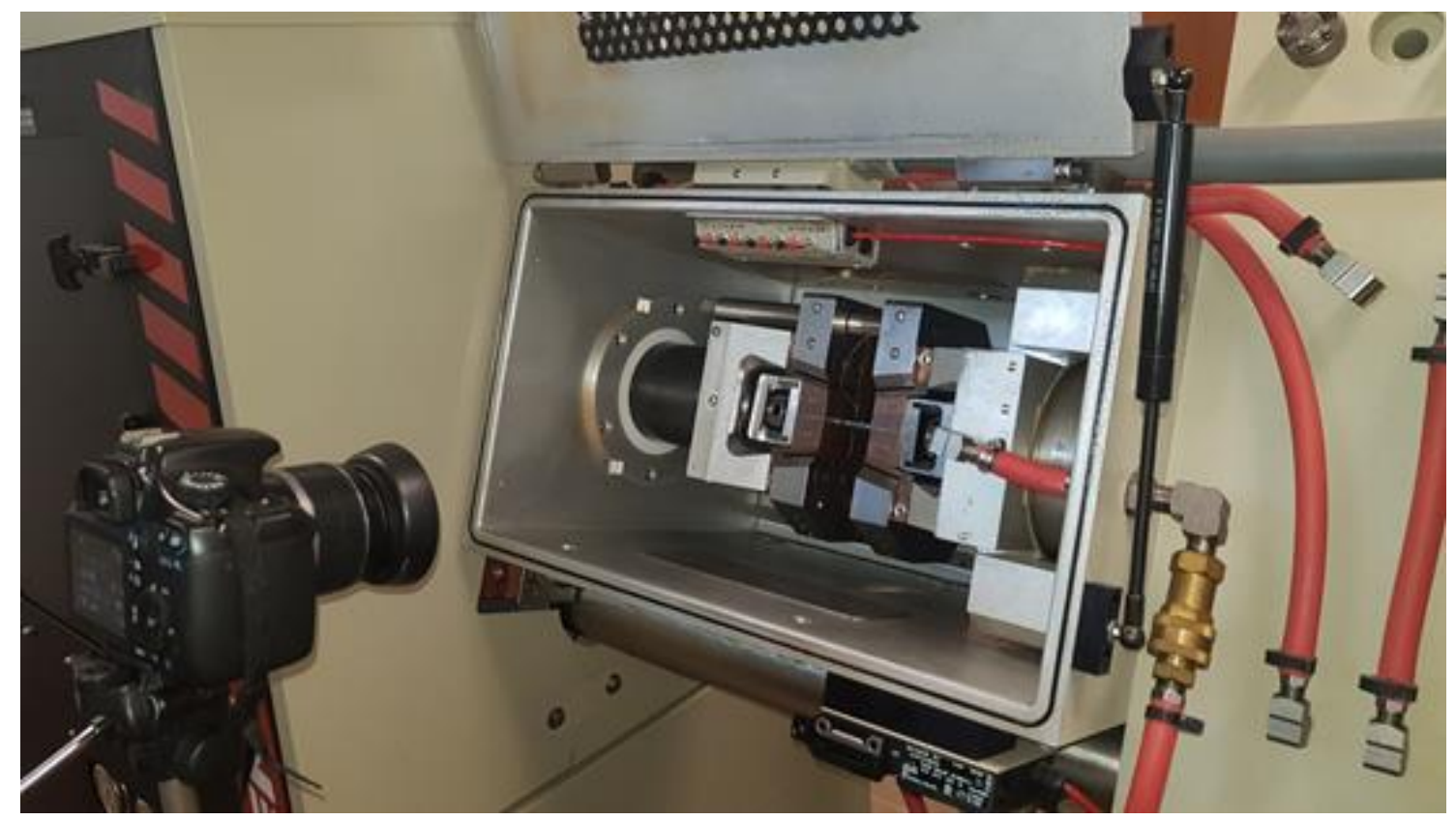

1. ábra. A vizsgálati összeállitás 


\subsection{Felületi oxidáció fizikai szimulációjának kivitelezése}

A fizikai szimuláció során $200 \ldots 700^{\circ} \mathrm{C}$ intervallumban szerettük volna előállítani a felület oxidációs színét $10{ }^{\circ} \mathrm{C}$-os hőmérsékletközökkel. Ennek érdekében a próbatestet egylépcsőben $20^{\circ} \mathrm{C} / \mathrm{s}$ hevítési sebességgel $200^{\circ} \mathrm{C}$-ra hevítettük, majd egyperces hőntartás után $10{ }^{\circ} \mathrm{C}$-kal emeltük a hőmérsékletet egészen addig, amíg el nem értük a $700^{\circ} \mathrm{C}$-ot. Ennek megfelelően a GLEEBLE programozása során a hőmérséklet időbeni változását a 2 . ábra tartalmazza, a diagramban a fekete vonal az elöre meghatározott program hőmérsékletet, míg a piros vonal a tényleges hőmérsékletet jelöli. Minden izoterma esetén a 40. másodpercben felvétel készült a felületről, amelyek segítségével az adott hőmérsékletlépcsőre jellemző oxidációs szín dokumentálásra került, és a későbbi feldolgozás során meghatározhatóvá vált.

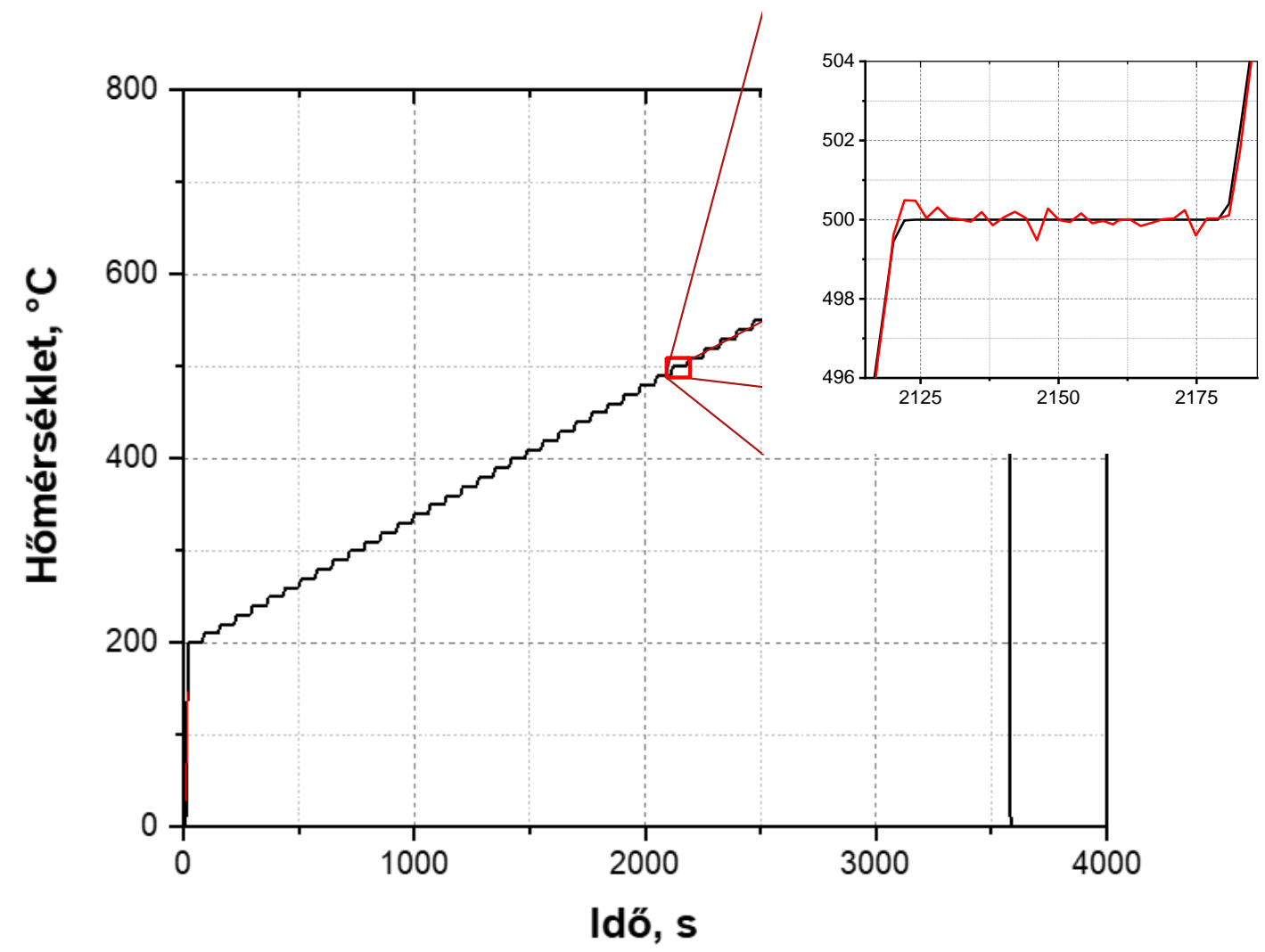

\section{2. ábra. Programozott hömérséklet időbeli változása}

Összesen három azonos vizsgálatot végeztünk azonos hőmérsékletprofillal és fényképezőgép beállításokkal (illetve anyagminőségen), ám különböző felületekkel. Az első vizsgálat során észleltük, hogy az esztergált hengeres felület esetében nem lehetett homogén megvilágítást alkalmazni, minek hatására a keletkezett színt nehéz volt meghatározni adott hőmérséklet esetén.

A második vizsgálat során (Négyzetes I.) $10 \times 10 \mathrm{~mm}$ méretű négyzet keresztmetszetű próbatestet használtunk, aminek a felületi minősége az utolsó megmunkálásnak megfelelően viszonylag nagy, az átlagos felületi érdessége $\left(\mathrm{R}_{\mathrm{a}}\right) 10 \mu \mathrm{m}$ feletti volt. A GLEEBLE-be befogott négyzet keresztmetszetü próbatestet mutat a 3. ábra. 


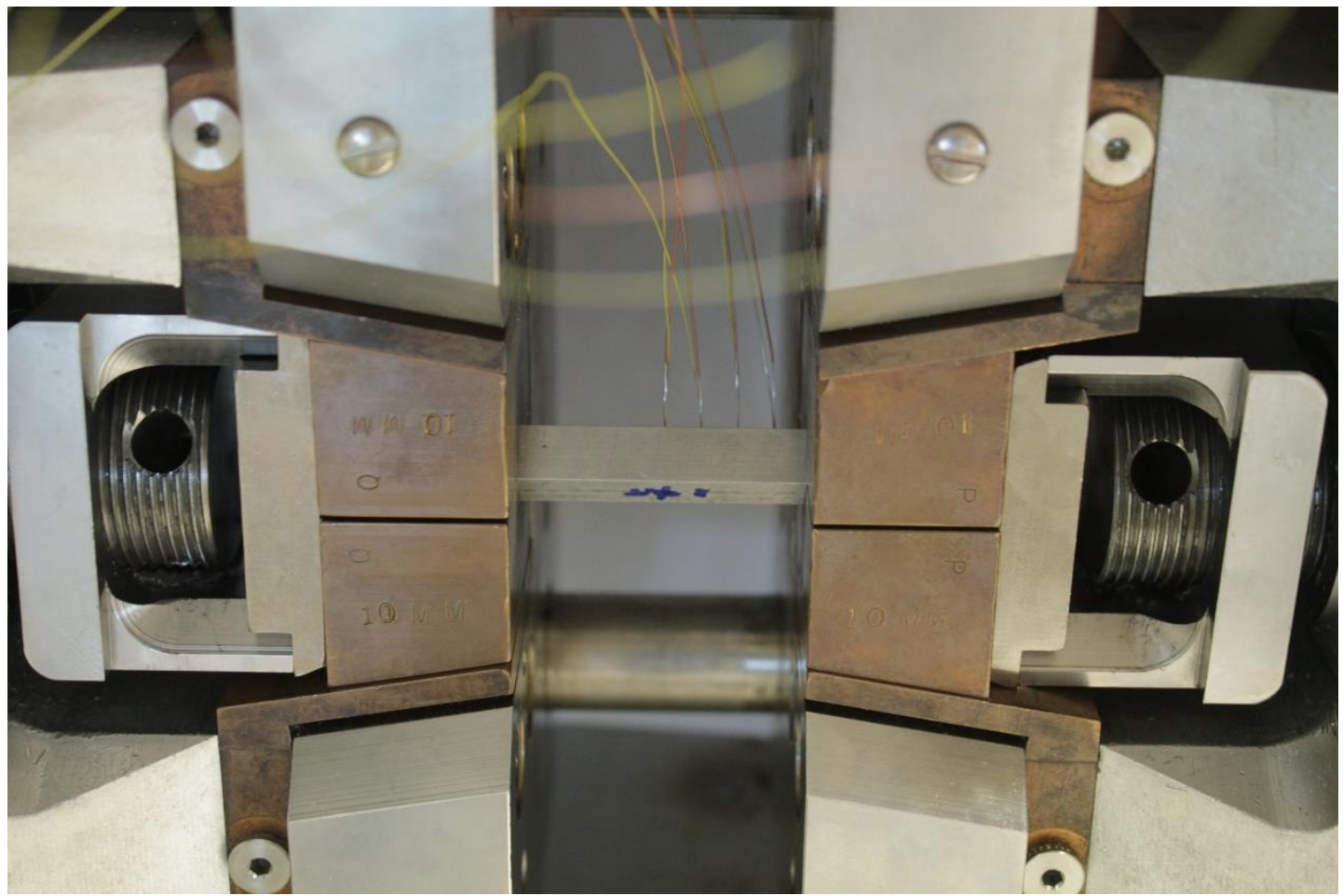

3. ábra. Négyzetes próbatest befogva

A harmadik vizsgálatsorozat során (Négyzetes II.) a felületi érdesség hatását is elimináltuk avval, hogy a vizsgált felületet csiszoltuk, majd políroztuk, így $1 \mu \mathrm{m}$ alatti felületi érdességet értünk el.

A három próbatest esetén különböző hőmérsékleten keletkezett oxidációs színeket a 4. ábra mutatja.

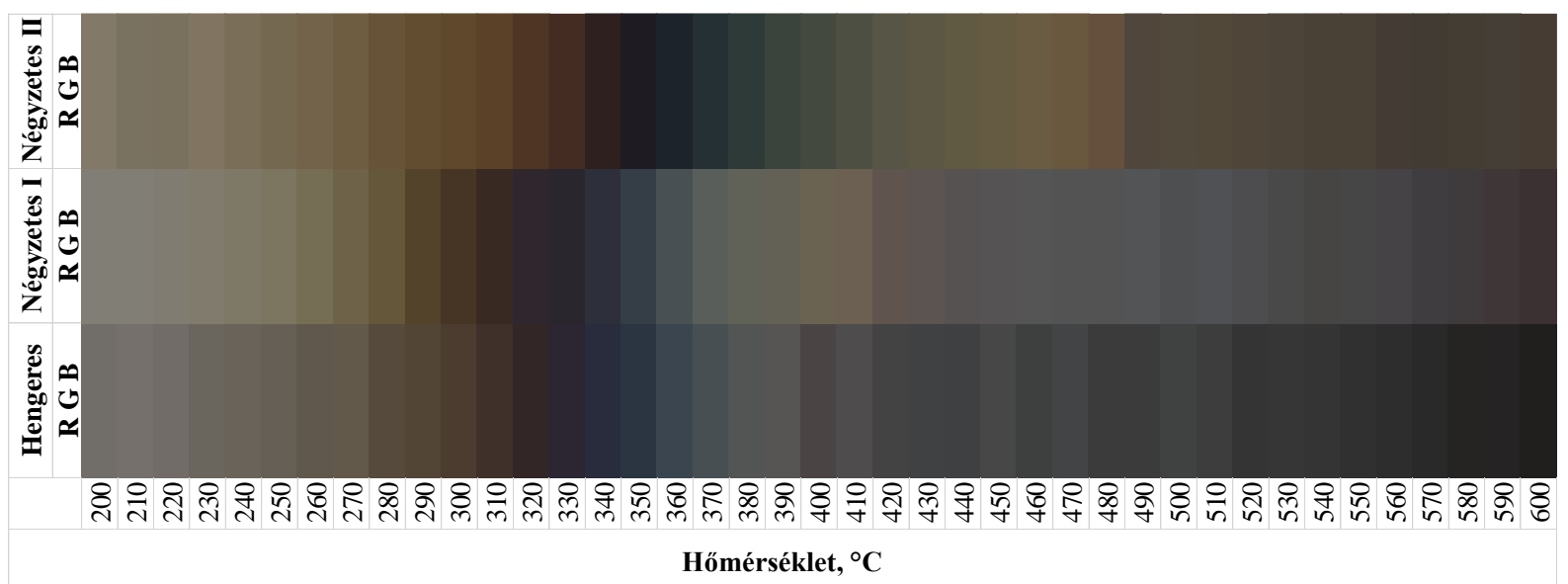

4. ábra. A különbözö hömérsékleten keletkezett oxidációs szinek a három próbatest esetében 


\section{3. Összefoglalás}

A bemutatott munka során S355J2SN jelölésü acél esetében $200 \ldots 700^{\circ} \mathrm{C}$ hőmérséklettartományban $10^{\circ} \mathrm{C}$-os lépcsőben állítottuk elő az adott hőmérsékletre jellemző oxidációs színt termomechanikus fizikai szimulátor segítségével.

A vizsgálatsorozat során megállapítottuk, hogy hengeres próbatesten nem lehetetett egyértelmüen megállapítani a keletkezett oxidációs színt a geometriából adódó egyenlőtlen megvilágítás miatt.

Négyzetes próbatestekkel, sokkal egyöntetübben lehet megállapítani a keletkezett oxidációs színt.

A végső megmunkálás utáni felületi érdesség szintén nagymértékben befolyásolta az adott hőmérsékleten keletkező oxidációs színt (Négyzetes I. és Négyzetes II.), standardizált vizsgálatok esetében ezért mindig törekedni kell az azonos kiinduló felületi érdességre.

Az oxidációs színek megállapítása különösen hasznos lehet sarokvarratok készítésekor vékonylemezek esetén. A gyökoldalon megjelenő futtatási színek egyszerű szemrevételezésével következtetni lehet a hegesztett kötés minőségére és a mechanikai tulajdonságokra. Ennek megállapítására minden anyagminőség esetében a hegesztett anyagokkal megegyező felületi érdességgel rendelkező próbatesttel kell felvenni a futtatási színskálát.

\section{Köszönetnyilvánítás}

A cikkben ismertetett kutató munka az EFOP-3.6.1-16-2016-00011 jelü „Fiatalodó és Megújuló Egyetem - Innovatív Tudásváros - a Miskolci Egyetem intelligens szakosodást szolgáló intézményi fejlesztése" projekt részeként - a Széchenyi 2020. keretében - az Európai Unió támogatásával, az Európai Szociális Alap társfinanszírozásával valósul meg.

The described presentation was carried out as part of the EFOP-3.6.1-16-2016-00011 'Younger and Renewing University - Innovative Knowledge City - institutional development of the University of Miskolc aiming at intelligent specialisation' project implemented in the framework of the Szechenyi 2020 program. The realization of this project is supported by the European Union, co-financed by the European Social Fund."

\section{Irodalomjegyzék}

[1] Barwell, F. T., Bowen, E. R., Bowen, J.P., Westcott V. C.: The use of temper colors in ferrograprhy; Wear 1977, 44:163-171. https://doi.org/10.1016/0043-1648(77)90093-X

[2] MSZ EN 10025-2:2005.

[3] Koncsik, Zs., Fótos, R., Lukács, J.: A fizikai szimuláció és alkalmazása az anyagtechnológiákban, Müszaki Tudomány az Észak-kelet Magyarországi Régióban, 2012. konferencia előadásai: Szolnok, 2012. május 10. (2012.) ISBN:9789637064289 pp. 211-217

[4] Adel, D., Koncsik, Zs.: Analysing the Softening of S960M by Physical Simulation, XXXI. microCAD International Multidisciplinary Scientific Conference. (2017) ISBN:9789633581322, 8 p.

[5] Sisodia, R., Gáspár, M., Nourreddine, G.: HAZ Characterization of Automotive DP Steels by Physical Simulation, International Journal of Engineering and Management Sciences / Müszaki és Menedzsment Tudományi Közlemények 2019, 4(1):478-487. 
[6] Bereczki, P., Fekete, B., Szombathelyi, V., Misjak F.: Different Applications of the Gleeble Thermal-Mechanical Simulator in Material Testing, Technology Optimization, and Process Modelling; July, 2015. https://doi.org/10.1520/MPC20150006

[7] Adonyi, Y.: Heat-Affected Zone Characterization by Physical Simulations, Welding Journal 2006, 85(10):42-47. 